\title{
Editorial
}

\section{Rethinking Radical Inclusiveness: A Theoretical Provocation}

\author{
Teguh Wijaya Mulya \\ Faculty of Psychology \\ Universitas Surabaya
}

\begin{abstract}
The notions of human rights and identity politics have been widely drawn on in the contemporary understandings and practices of developing more inclusive cities. Examining the UN Habitat III Issue Paper on Inclusive Cities (2015), in this article I attempt to identify and problematize some assumptions that might have underpinned our efforts to improve the inclusiveness of our cities. I argue that a liberal view of human being has constrained the understandings about who "everyone" is, the nature of their sense of self, and what they want; which subsequently might exclude and marginalise those who do not fit our conceptions. Alternatively, I will draw on poststructuralist theorisation of discourse and subjectivity to offer a new way of thinking about human rights and identity politics, and discuss how it might contribute to our understanding and practices of inclusiveness.
\end{abstract}

Keywords: inclusiveness, inclusive cities, identity politics, human rights, subjectivity

Konsep hak asasi manusia dan politik identitas telah digunakan secara luas dalam pemahaman dan praktik kontemporer pengembangan kota inklusif. Dalam artikel ini saya akan mengaji dokumen PBB Habitat III tentang kota inklusif dengan tujuan mengidentifikasi dan menyoal asumsi-asumsi yang mungkin telah melandasi usaha-usaha untuk menjadikan kota kita lebih inklusif. Saya berargumen bahwa pandangan liberal tentang manusia telah membatasi pemahaman tentang siapa "semua orang" itu, hakikat pemahaman diri mereka, dan apa yang mereka inginkan; sehingga berpotensi mengeksklusi dan meminggirkan mereka yang tidak cocok dengan konsepsi tersebut. Sebagai alternatif, saya menggunakan konsep wacana dan subjektivitas dari teori pasca-strukturalis untuk menawarkan pandangan baru memahami hak asasi manusia dan politik identitas, dan bagaimana pandangan ini dapat berkontribusi bagi pemahaman dan praktik keinklusifan kontemporer.

Kata kunci: keinklusifan, kota inklusif, politik identitas, hak asasi manusia, subjektivitas

In this editorial article I seek to offer a theoretical provocation in relation to the notion of inclusiveness and inclusive cities. My discussion here is predicated on a premise that an inclusive city starts from inclusive ways of thinking, and promoting inclusive ways of thinking involves continuous resistance towards our current ways of seeing and being inclusive. Following this premise, I attempt to identify and problematize some assumptions that might have underpinned our efforts to build more inclusive cities. Specifically, I will draw on poststructuralist con-

Correspondence concerning this editorial article should be addressed to Teguh Wijaya Mulya, Faculty of Psychology Universitas Surabaya. Jalan Raya Kalirungkut Surabaya 60293. E-mail: teguh @ubaya.ac.id ceptualisation of discourse and subjectivity to offer a new way of thinking about human rights and identity politics, and how it might contribute to our understanding and practices of inclusiveness.

I will start by citing one of the recommendations from the UN Habitat III Issue Paper on Inclusive Cities (2015, May 31, p. 8):

Urbanization processes should be more firmly entrenched in a human rights framework that ensures the alignment of goals and implementation processes to specific human rights obligations while promoting the accountability of local governments with respect to evolve from technocratic models to rights-based models that ensure 
the accountability and responsibility and the entitlements of city dwellers as, who are human rights-holders (my emphasis).

This excerpt is an example of how the notion of human rights has been central to and frequently referred in UN Habitat's strategies to develop inclusive cities. An inclusive city is understood as a city that respects the rights of its dwellers. Underpinning this centrality is the liberal construction of human being as having universal rights despite their race, ethnicity, religion, class, gender, sexuality, and so on; that should be protected by the state. As Martha Nussbaum (1999, p. 54) has argued that: “... all, just by being a human, are of equal dignity and worth, no matter where they are situated in society, and that the primary source of this worth is a power of moral choice within them." Nussbaum also emphasises how this "essence" of being human, that is, the ability to make moral choices, must be protected by the state:"This [state] treatment [of the people] must do two . . . things [:] respect and promote the liberty of choice, and ...respect and promote the equal worth of persons as choosers" (1999, p. 54). Here, individuals are constituted as universally equal, able to make choices autonomously, and their choices must be respected with regards to their basic rights.

Accordingly, Nussbaum (2011, pp. 33-34) has proposed ten qualities that must be there if we are going to acknowledge that a given life is human: life, bodily health, bodily integrity, senses-imaginationthought, emotions, practical reason, affiliation, concerns for other species, play, and control over one's environment. Coming from a country with a number of cases of human rights abuses throughout the history, I concur with Nussbaum that such respect for human dignity through the notion of human rights is of paramount importance.

However, as in any way of understanding human nature, this liberal view on human being might not always be sufficient to represent all the complexities of social reality. The view on human as non-essentialist but discursively constituted, for instance, might not be completely compatible with this liberal stance. Some theoretical traditions, such as poststructuralism, espouse the view that there is no objective and universal essence of human, but rather, human nature is always constituted differently in different historical times and cultural contexts (Foucault, 1978; Weedon, 1987).

A first-century Greco-Roman society, for instance, might understand the essence of being a human very differently from a twenty-first century indigenous tribe in rural Indonesia. The way individuals under- stand themselves, their worlds, and what makes sense for them, are both enabled and constrained by discourses available in their specific situation (Weedon, 1987). Another example is the identity as a gay or a lesbian, which is not available prior to the 19th century. It is not because there was no same-sex attraction prior to that time, but because there were no discourses through which people could understand the same-sex attraction as an identity (Foucault, 1978). In this way, individuals are not essentially autonomous or free to make choices. Instead, their ways of being are (re)produced by power relations, and choices they made are always dependent on the ever-changing discursive resources to which they have access. Consequently, what we now firmly believe as the essence of being human might be very different in the future, or in other cultures.

Following this poststructuralist view on human's understanding of themselves, the claim of universal rights based on the "essence" of being human becomes problematic. Since there is no such "essence," a claim of universal human rights is understood as a product of discursive mechanisms and practices, and thus, is open to contestation. As the history has evidenced, the notion of human rights is not always universal and straightforward, but rather, complex and contested. Plummer (2010, p. 47) has stated that "those who suggest that [human] rights are straightforward, inalienable, and uncontested-and many do-work from a shallow and culturally limited ideas of rights." Further, defining what universal human rights are implies defining what it means to be human, or in other words, to define the nature of humanity (Plummer, 2010). This is a huge task. It cannot aim for a single universal claim, considering the diversity of cultures, worldviews, and ways of being - with each of these having their own views of humanity.

One example is the uneasy relationship between religion and human rights movement. Based on their own views of humanity, most religions in the world have certain beliefs or practices that basically violate human rights; from killing people in the name of God, justifying domestic violence, to condemning lesbian and gay sexualities. Unsurprisingly, the World Report of Human Rights Watch documented a growing conflict between religion and human rights initiatives (Nathan, 2009). While certainly there are possibilities of integration of religions and human rights-as it has been documented in some previous studies (Langan, 1998; Newlands, 2006; Rehman \& Breau, 2007); here I draw attention to the possibility that, like religions, human rights might not be universal and 
eternal; rather, it is one among many belief systems, with its own views of and ontological assumptions about humanity.

In the same vein, the notion of inclusiveness itself might not be self-explanatory, objective, or universal; but as a discourse, it is continuously circulating and shifting, strengthened and resisted. This poststructuralist view can be useful to examine and expand our understanding and practices of inclusiveness. For instance, the UN Habitat III Issue Paper on Inclusive Cities (2015, May 31, p. 4) has stated that "effective implementation of human rights, equality and nondiscrimination cannot be achieved without the proactive involvement of local and subnational governments." While I agree with and support this statement, we might also need to consider that not all governments have agreed and supported the aspiration of inclusiveness as the common good. Thus, circulating inclusiveness through certain ways of thinking that make sense for those governments, such as through a discourse of democracy, might add more values in building more inclusive cities.

Another limitation of the concept of inclusiveness based on human rights can be found in its reliance on the notion of identity. Identity is often seen as relatively fixed, categorical, and attached to one's sense of self. Being a woman, for instance, is often viewed as an essential identity someone has from birth. In contrast, poststructuralism understands subjectivity-that is, one's sense of self-as multiple, contradictory, and continuously reworked (Weedon, 1987). There is no fixed or essentialist identity attached to oneself. As Simone de Beauvoir has famously said, one is not born a woman, but rather becomes a woman - and what it means to be a woman is always different throughout the history, discursively constituted, and open to negotiations.

It is quite different from the meanings circulated through the discourse of human rights, which often rely on the mechanisms of identity politics, where relatively stable "identities" must be specifically defined-such as Black, woman, gay, or disabledbefore they can be recognised, and then protected. Consequently, inclusiveness based on the concept of human rights might only apply to those who are willing to be defined by these categories (Kollman \& Waites, 2009; Stychin, 1995). Someone who refuses to identify, specify, or label their gender, for instance, cannot be recognised and thus cannot be included and protected. To access disability or mental health services and benefits, one must take up the "disabled" or "mentally ill" subject positions and be defined according to the dominant meanings around those labels.

The UN Habitat III Issue Paper on Inclusive Cities (2015, May 31, pp. 5-6) has proposed some strategies towards inclusive cities; I argue that some of them might have relied on identification and specification of marginalised groups and identities:

Supporting excluded urban groups to share their views and represent their own needs: An essential aspect of ensuring inclusion and meaningful participation by all is through the mobilization of excluded groups themselves, whose ability to engage with more powerful stakeholders is greatly enhanced through collective action (my emphasis). It is essential to assess the way these services are accessible and utilized according to the different needs of other marginalized groups, such as indigenous peoples, migrants, ethno-cultural specificities of communities, women with disabilities, adolescent girls, older persons and others in the decision making processes related to urban planning (my emphasis).

While I believe these strategies are considerably important in democratising city planning and promoting more inclusive cities-and thus must be carried out immediately-they might also be limited in the way they position these marginalised groups as identifiable, specifiable, have similar characteristics (perhaps even unified), and able to straightforwardly voice their needs. My own ethnicity, for example, is much more complex and contradictory than a simple label of "Chinese Indonesian." As the third generation of Chinese in Indonesia, my physicality still expresses my Chinese-ness. However, since my parents' early conversion to Christianity, my family has lost most of our Chinese cultural traditions. Unlike my Chinese Indonesian friends from outside Java, I do not speak Chinese at all. Lacking in curiosity about my Chinese heritage, I found a sense of connectedness and fascination with my local Indonesian Javanese culture. From this uncertain and complicated position, how can I voice what Chinese Indonesians as an ethnic group need or want?

Considering this limitation of identity politics, I propose that working towards more inclusive cities might need to involve some contradictory moves. On the one hand, in our attempt to include everyone we need to identify and specify marginalised groups, listen to their voices and accommodate their needs. On the other hand, we need to be critical of the messages or discursive positioning that we reproduce through such efforts, which in return, might further 
constrain these groups' possibility to see themselves differently. In describing poor migrant women, for example, have we overly and merely represented them as low-skilled, underpaid, abused, unable to access basic services, lack of decision making opportunities, and exposed to pollution, crime, and environmental threats? In engaging with young people, have we continuously positioned them as unproductive, are fuelled by their raging hormones, not knowing what to do with their live, full of potentials-but unless we facilitate them-they cannot lead healthy and productive lives? The challenge is to find the balance between recognising both their vulnerability and capability, and acknowledging their agency without relinquishing our responsibility.

Finally, understanding inclusiveness as a discourse also requires continuous contestations of our current ways of seeing inclusiveness and inclusive practices - that our inclusiveness is always partial, incomplete, and in constant need to be expanded, challenged, and problematized. In our discussions on gender, for example, have we recognised and included transgendered people, not just men and women? When planning a more inclusive city, do we limit inclusiveness to humans and ignore other animals which should also have the right to live together harmoniously in our cities? And if we really pursue radical inclusiveness, what about mysterious forces that our scientific methodology has not been able to understand, but keep demonstrating their existence, subtly and silently? Will we humbly acknowledge and try to include them in our design of an inclusive city?

To conclude, in this editorial article I have offered a provocation regarding how-in our attempts to be inclusive-we might have relied on certain problematic assumptions about who "everyone" is, the nature of their sense of self, and what they want - which in turn, might have excluded and marginalised those who do not fit our conceptions. As a theoretical provocation, in this article I will not provide any practical recommendation, only an invitation to keep reflexively problematizing our understandings, practices, and assumptions about inclusiveness. However, an example of the embodiment of such invitation can be found in the UN Habitat III Issue Paper itself (2015, May 31, p. 5). Addressing strategies to be more inclusive with migrants, it recommends:
This includes promoting a more balanced approach to the perception of migrants: is essential to improve the current migration "narrative", which is essentially negative, to more accurately reflect contemporary migration realities; and the historically positive impact of human mobility on our societies, many of which have been built with the contributions made by migrants.

\section{References}

Foucault, M. (1978). The history of sexuality, vol. 1: The will to knowledge (R. Hurley, Trans.). New York: Pantheon Books.

Kollman, K., \& Waites, M. (2009). The global politics of lesbian, gay, bisexual and transgender human rights: An introduction. Contemporary Politics, 15(1), 1-17. doi: 10.1080/13569770802674188

Langan, J. (1998). Contrasting and uniting theology and human rights. The Journal of Religious Ethics, 26(2), 249-255.

Nathan, C. (2009). The changing face of religion and human rights. Leiden: Brill.

Newlands, G. M. (2006). Christ and human rights: The transformative engagement. Aldershot: Ashgate.

Nussbaum, M. C. (1999). Sex and social justice. Oxford: Oxford University Press.

Nussbaum, M. C. (2011). Creating capabilities: The human development approach. Cambridge: Harvard University Press.

Plummer, K. (2010). The social reality of sexual rights. In P. Aggleton \& R. Parker (Eds.), Routledge handbook of sexuality, health and rights (pp. 4555). New York: Routledge.

Rehman, J., \& Breau, S. C. (Eds.). (2007). Religion, human rights and international law: A critical examination of Islamic state practices. Leiden: Martinus Nijhoff.

Stychin, C. F. (1995). Law's desire: Sexuality and the limits of justice. London: Routledge.

United Nations. (2015, May 31). Habitat III issue paper on inclusive cities. Retrieved from http:// unhabitat.org/wp-content/uploads/2015/04/ HabitatIII-Issue-Paper-1_Inclusive-Cities-2.0.pdf

Weedon, C. (1987). Feminist practice and poststructuralist theory. Oxford: Blackwell. 